\title{
LABORATORY EVALUATION OF FR10612, A NEW ORAL CEPHALOSPORIN DERIVATIVE
}

\author{
Minoru Nishida, Takeo Murakawa, Toshiaki Kamimura, \\ Naohiko OKada, Hiroshi SaKamoto, Shigemi Fukada, \\ ShojI NaKamoto, Yoshiko Yokota and KazUYo Miki \\ Research Laboratories, Fujisawa Pharmaceutical Co., Ltd., \\ Osaka, Japan \\ (Received for publication February 12, 1976)
}

\begin{abstract}
FR10612, like cephalexin, is a broad-spectrum oral cephalosporin derivative. The antimicrobial activity of FR10612 against clinical isolates was similar to cephalexin; however, at a low inoculum size its activity was greater than cephalexin against Klebsiella pneumonia and Proteus mirabilis strains. Like cephalexin, the in vitro bactericidal activity of FR10612 was more influenced by the duration of contact with the test organism than by drug concentration. The bactericidal activity of FR10612 against E. coli 317 was greater than that of cephalexin in an in vitro model system which simulated the serum levels of FR10612 and cephalexin achieved in healthy volunteers after a single oral dose. The protein binding of FR10612 to human and animal serum was extremely low. FR10612 was resistant to $\beta$-lactamases from gram-negative bacilli. It showed resistance similar to cephalexin, but was more resistant to $\beta$-lactamases than were cephaloridine, cephalothin and cefazolin.

The protective effect of FR10612 in mice infected with various pathogens was greater than cephalexin.

The serum levels of FR10612 in rats were higher and more prolonged than those of cephalexin. Tissue levels of FR10612 in rats also persisted for a long time period reflecting the serum levels. In healthy volunteers, rabbits and monkeys the serum levels of FR10612 were initially lower than those of cephalexin but persisted for a longer time period. The total 24-hour urinary excretion of FR10612 in healthy volunteers after oral administration was almost the same as that of cephalexin, but the excretion rate of FR10612 was slower, and the urinary levels were more persistent than those of cephalexin.
\end{abstract}

Following the development of cefazolin, ${ }^{1)}$ ceftezole $^{2)}$ and other injectable cephalosporin derivatives, a number of oral cephalosporin derivatives have been synthesized and evaluated by Fujisawa Research Laboratories. In this paper the in vitro and in vivo antimicrobial activity, absorption and excretion of one of these new cephalosporin derivatives, FR10612, will be reported. Its chemical structure is shown in Fig. 1. In a number of instances its characteristics will be compared with cephalexin.

\section{Materials and Methods}

1. Test antibiotics

FR10612 and cefazolin (CEZ) were provided by Fujisawa Research Laboratories, cephalexin (CEX), cephaloridine (CER) and cephalothin (CET) by Eli Lilly \& Company, and ampicillin (ABPC) by Beecham Research Laboratories.

2. Subjects

Mouse: 4 week old male mice, ICR strain, each weighing $20 \sim 26 \mathrm{~g}$.

Rat: 6 week old male rats, SD strain, each weighing $160 \sim 230 \mathrm{~g}$. 
Fig. 1. Structure of FR10612.

7-[D-2-(3-Mesylaminophenyl)-glycinamido]-3methyl-3-cephem-4-carboxylic acid.

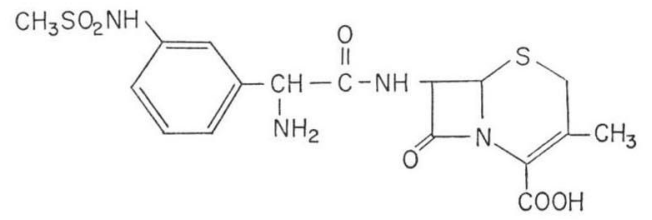

Rabbit: Male white rabbits, each weighing $2.2 \sim 2.8 \mathrm{~kg}$.

Dog: Male beagle dogs, each weighing $9.0 \sim 11.0 \mathrm{~kg}$.

Monkey: Male rhesus monkeys, each weighing $6.2 \sim 9.8 \mathrm{~kg}$.

Man: Healthy adult male volunteers, each weighing $49 \sim 70 \mathrm{~kg}$.

3. Determination of in vitro antimicrobial activity

The in vitro antimicrobial activity of the test antibiotics was determined by the agar dilution method. An overnight broth culture and decimal dilutions thereof were spot-inoculated using a multiple inoculator on heart infusion agar (Difco) containing graded concentrations of the test drugs. The minimum inhibitory concentration (MIC) was estimated after incubation at $37^{\circ} \mathrm{C}$ for 20 hours. For Streptococcus and Corynebacterium diphtheriae, $10 \%$ rabbit blood was added to the above media. For anaerobic bacteria the MICs of the test antibiotics were determined using GAM agar after incubation at $37^{\circ} \mathrm{C}$ for 48 hours.

4. Bactericidal activity

Heart infusion broth containing the MIC to 50 times the MIC of each antibiotic was inoculated with $E$. coli 324 to obtain a final concentration of $10^{\circ} \mathrm{cells} / \mathrm{ml}$ and was then incubated without shaking at $37^{\circ} \mathrm{C}$ for $1.5,3.0$ and 6.0 hours. The viable cell counts at each concentration were measured.

In another experiment which attempted to simulate human serum levels obtained at various time intervals following oral administration of $500 \mathrm{mg}$ of FR10612 or cephalexin to healthy volunteers, each antibiotic was added to heart infusion broth containing $2.4 \times 10^{5} \mathrm{cells} / \mathrm{ml}$ of E. coli 317 . The antibiotic concentration was adjusted at specific time intervals so that it equalled the corresponding serum concentration. Viable cell counts were determined at each time interval.

5. Protein binding

To $4.5 \mathrm{ml}$ of fresh serum, $0.5 \mathrm{ml}$ of the antibiotic solution $(300 \mu \mathrm{g} / \mathrm{ml})$ in $\mathrm{M} / 15$ phosphate buffer ( $\mathrm{pH}$ 7.0) was added and incubated for one hour. This mixture was poured into a Visking tube (size : 8/32) and centrifuged at $1,000 \times g$ for 30 minutes. The free antibiotic levels in the ultrafiltrate were determined by the disc method, using Bacillus subtilis ATCC 6633 as the test strain.

6. Hydrolysis of antibiotics by $\beta$-lactamase

$\beta$-Lactamase solution $(0.2 \mathrm{ml})$ was added to $3 \mathrm{ml}$ of $\mathrm{M} / 15$ phosphate buffer ( $\mathrm{pH} 7.0$ ) containing $50 \mu \mathrm{g} / \mathrm{ml}$ of the test drugs. A Hitachi spectrophotometer Type 124 was used to determine the initial hydrolysis rate of the antibiotics as manifested by ultraviolet absorption changes due to the $\beta$-lactam ring. Hydrolysis rate was expressed in relative values using the initial hydrolysis rate of $50 \mu \mathrm{g} / \mathrm{ml}$ of cafazolin expressed as 100 .

7. Protective effect on infections

Male ICR strain mice aged 4 weeks, each weighing $20 \sim 24 \mathrm{~g}$ were used. Each group consisted of 10 mice. The organisms which had been precultured overnight on slant agar at $37^{\circ} \mathrm{C}$ were suspended in a standard mucin solution to obtain specified concentrations of the test organisms. Mice were inoculated intraperitoneally with $0.5 \mathrm{ml}$ of this suspension and each of the antibiotics was given orally at different doses to each group of the mice one hour after challenge. The $\mathrm{ED}_{50}$ values were found by the probit method from the number of mice surviving after two weeks of observation.

8. Serum levels

Either FR10612 or cephalexin $(100 \mathrm{mg} / \mathrm{kg})$ was given orally to groups of 10 rats which had been fasted overnight. At specified intervals, the rats were anesthetized with chloroform and blood samples were collected from the heart. For rabbits, dogs and monkeys, consisting of 
groups of 5 animals blood samples were collected from the foreleg at fixed intervals after 40 $\mathrm{mg} / \mathrm{kg}$ of antibiotic had been administered orally to the fasting animals. The antibiotic levels in each serum sample were determined by the disc method using standard solutions prepared with serum from each animal.

9. Urinary excretion

FR10612 or cephalexin was given to groups of 10 rats in the above mentioned manner, and urinary samples were taken at $0 \sim 6$ and $6 \sim 24$ hours. For groups of 5 dogs and 5 monkeys, urine samples were collected through a catheter at the specified intervals after oral administration of $40 \mathrm{mg} / \mathrm{kg}$ of the antibiotic.

10. Biliary excretion

Groups of 10 rats anesthetized with intraperitoneal pentobarbital were fixed in the supine position, and a polyethylene cannula was inserted into the bile duct. Bile samples were collected at $0 \sim 3,3 \sim 6$ and $6 \sim 24$ hours after oral administration of $100 \mathrm{mg} / \mathrm{kg}$ of the test antibiotics. The antibiotic levels in the bile samples were assayed with the standard solutions prepared with $\mathrm{m} / 15$ phosphate buffer at $\mathrm{pH} 7.0$ and biliary recovery was calculated.

11. Tissue distribution

Groups consisting of 9 rats and 30 mice were used in this experiment. The animals received $100 \mathrm{mg} / \mathrm{kg}$ of the test drugs orally and were then killed at set intervals and their organs were removed. After lightly washing the organs with saline solution, the organs were homogenized in ethanol in a Polytron homogenizer $(2 \mathrm{ml}$ ethanol $/ \mathrm{g}$ tissue). The antibiotic levels in the supernatants obtained by centrifuging the homogenate at $10,000 \times g$ for 10 minutes were bioassayed with the standard solutions prepared with $\mathrm{m} / 15$ phosphate buffer containing $66 \%$ ethanol $(\mathrm{pH}$ 7.0). The tissue levels of the test antibiotics were then calculated.

12. Antibiotic levels in exudate of rats with granuloma pouch

After subcutaneous injection of $20 \mathrm{ml}$ of air into the back of 8 rats, $1 \mathrm{ml}$ of olive oil containing $1 \%$ of croton oil was injected into the pouch to induce aseptic inflammation. Each of the test antibiotics was given orally $100 \mathrm{mg} / \mathrm{kg}$ on the 7 th day after formation of the pouch and the exudate was collected at specified intervals. The antibiotic levels in the exudates were bioassayed with the standard solutions diluted with the exudates.

13. Absorption and excretion of the antibiotics in healthy volunteers

The serum and urinary levels of FR10612 and cephalexin were determined at fixed intervals in 6 healthy volunteers after oral administration of 250 and $500 \mathrm{mg}$ of FR10612 and of $250 \mathrm{mg}$ of cephalexin in the fasting state.

14. Antimicrobial substances in urine and bile

FR10612 was given orally to rats, dogs, monkeys and healthy volunteers, and urine was collected at fixed intervals. Bile was also collected for 3 hours from the rats. The active substances were identified using thin-layer chromatography and bioautography. B. subtilis ATCC 6633 was used as the test organism in the bioautography.

\section{Results}

\section{Antimicrobial Spectrum}

As is shown in Table 1, FR10612, like cephalexin acts as a broad-spectrum antibiotic with antimicrobial activity against gram-positive and gram-negative organisms. However, it does not have antimicrobial activity against Streptococcus faecalis, Proteus vulgaris and Pseudomonas aeruginosa. FR10612, like other cephalosporin derivatives, is active against the anaerobic bacteria except Bacteroides, Fusobacterium and Propionibacterium.

\section{Sensitivity Distribution}

The sensitivity distribution of 42 strains each of Staphylococcus aureus, E. coli, Klebsiella pneumoniae and $P$. mirabilis isolated from patients to FR10612 was compared with that of 
cephalexin at an inoculum of $10^{6}$ cells/ml (Table 2).

The MICs of FR10612 against 42 strains of $S$. aureus ranged from 0.78 to $12.5 \mu \mathrm{g} / \mathrm{ml}$ with a median value of $3.13 \mu \mathrm{g} / \mathrm{ml}$ (23 strains, $54.8 \%$ ). No strains resistant to FR10612 and cephalexin were detected. There were no significant differences in MIC distribution between FR10612

Table 1. Antimicrobial spectra of FR10612 and cephalexin against aerobic and anaerobic bacteria.

(1) Aerobic bacteria

\begin{tabular}{|c|c|c|}
\hline \multirow{2}{*}{ Organism } & \multicolumn{2}{|c|}{ MIC: $\mu \mathrm{g} / \mathrm{ml}$} \\
\hline & FR10612 & CEX \\
\hline S. aureus 209P JC-1 & 3.13 & 9.25 \\
\hline S. aureus Newman & 3.13 & 3.13 \\
\hline S. aureus Terashima & 12.5 & 12.5 \\
\hline S. aureus Smith & 3.13 & 3.13 \\
\hline S. aureus ATCC 6538-P & 12.5 & 6.25 \\
\hline B. subtilis ATCC 6633 & 0.78 & 0.78 \\
\hline B. subtilis $\mathrm{PCI}-219$ & 0.78 & 0.78 \\
\hline M. luteus PCI-1001 & 0.1 & 0.1 \\
\hline *S. pneumoniae III & 6.25 & 3.13 \\
\hline *S. pyogenes S- 23 & 0.78 & 0.78 \\
\hline *S. pyogenes A-S-8 & 0.78 & 1.56 \\
\hline *S. faecalis 6733 & $>100$ & $>100$ \\
\hline${ }^{*}$ C. diphtheriae $\mathrm{PW}-8$ & 0.78 & 0.39 \\
\hline *C. diphtheriae A-7 & 1.56 & 1.56 \\
\hline *C. diphtheriae M $406 \mathrm{MGL}$ & 3.13 & 1.56 \\
\hline E. coli NIHJ JC-2 & 25 & 25 \\
\hline E. coli Yukitoshi & 6.25 & 6.25 \\
\hline E. coli $\mathrm{K}-12$ & 3.13 & 1.56 \\
\hline K. pneumoniae NCTC-418 & 3.13 & 6.25 \\
\hline P. vulgaris IAM-1025 & $>100$ & 100 \\
\hline P. vulgaris $\mathrm{OX}-19$ & 100 & 100 \\
\hline P. aeruginosa IAM-1095 & $>100$ & $>100$ \\
\hline S. typhi $\mathrm{T}-287$ & 3.13 & 3.13 \\
\hline S. typhi O-901 & 3.13 & 3.13 \\
\hline S. paratyphi A 1015 & 6.25 & 12.5 \\
\hline S. schottmueller 8006 & 6.25 & 6.25 \\
\hline S. typhimurium 1406 & 3.13 & 12.5 \\
\hline S. enteritidis 1891 & 3.13 & 6.25 \\
\hline S. dysenteriae Al Shiga & 12.5 & 6.25 \\
\hline S. flexneri 1a EW-8 & 6.25 & 12.5 \\
\hline S. flexneri 1b Showa 15 & 12.5 & 12.5 \\
\hline S. flexneri 2 a Komagome B III & 12.5 & 12.5 \\
\hline S. flexneri $3 \mathrm{a}$ EW-14 & 12.5 & 12.5 \\
\hline S. flexneri 4a Saigon-Arai & 12.5 & 6.25 \\
\hline S. sonnei I EW-33 & 6.25 & 6.25 \\
\hline S. sonnei II EW-34 & 25 & 12.5 \\
\hline
\end{tabular}

HI-Agar, $37^{\circ} \mathrm{C}, 20$ hours

Inoculum: $10^{8}$ cells $/ \mathrm{ml}$

* supplemented with $10 \%$ rabbit blood 
(2) Anaerobic bacteria

\begin{tabular}{|c|c|c|}
\hline \multirow{2}{*}{ Organism } & \multicolumn{2}{|c|}{ MIC: $\mu \mathrm{g} / \mathrm{ml}$} \\
\hline & FR10612 & CEX \\
\hline Peptococcus asaccharolyticus Z-1003 & 1.56 & 0.78 \\
\hline P. aerogenes PL-4-2 & 3.13 & 0.78 \\
\hline P. prevotii ATCC 9321 & 3.13 & 1.56 \\
\hline P. anaerobius ATCC 14955 & 12.5 & 12.5 \\
\hline Peptostreptococcus anaerobius NCTC 9801 & 0.78 & 0.39 \\
\hline Eubacterium lentum $\mathrm{H}-1$ & 12.5 & 12.5 \\
\hline Propionibacterium avidum B-38 & $>100$ & $>100$ \\
\hline Clostridium perfringens SAKAI & 3.13 & 6.25 \\
\hline Fusobacterium necrophorum W-12 & 3.13 & 0.78 \\
\hline F. mortiferum $\mathrm{H}-14$ & $>100$ & $>100$ \\
\hline F. glutinosum $\mathrm{J}-2-43$ & $>100$ & $>100$ \\
\hline F. nucleatum B-1 & 1.56 & 0.39 \\
\hline F. varium ATCC 8501 & $>100$ & $>100$ \\
\hline Bacteroides fragilis ss distasonis W-7 & $>100$ & $>100$ \\
\hline B. $f$. ss vulgatus W-6 & 100 & $>100$ \\
\hline B. melaninogenicus ss melaninogenicus W-9 & 50 & 50 \\
\hline Veillonella parvula ATCC 10790 & 25 & 12.5 \\
\hline
\end{tabular}

Medium: GAM-Agar (Eiken)

Inoculum: $10^{8}$ cells $/ \mathrm{ml}$

Incubation: $37^{\circ} \mathrm{C}, 48$ hours, Gas pak method

Table 2. Distribution of susceptibilities of clinical isolates to FR10612 and cephalexin.

\begin{tabular}{|c|c|c|c|c|c|c|c|c|c|c|c|c|c|}
\hline \multirow{2}{*}{ Organism } & \multirow{2}{*}{ Antibiotic } & \multicolumn{12}{|c|}{ MIC: $\mu \mathrm{g} / \mathrm{ml}$} \\
\hline & & $\leqq 0.1$ & 0.2 & 0.39 & 0.78 & 1.56 & 3.13 & 6.25 & 12.5 & 25 & 50 & 100 & $>100$ \\
\hline \multirow{2}{*}{ S. aureus 42 strains } & FR10612 & & & & 1 & 5 & 23 & 11 & 2 & & & & \\
\hline & CEX & & & & 1 & 14 & 19 & 6 & 1 & 1 & & & \\
\hline \multirow{2}{*}{ E. coli 42 strains } & FR10612 & & & & & 2 & 4 & 15 & 15 & 2 & & & 4 \\
\hline & CEX & & & & & & 5 & 21 & 11 & 1 & & & 4 \\
\hline \multirow{2}{*}{ K. pneumoniae 42 strains } & FR10612 & & & & & 8 & 33 & 1 & & & & & \\
\hline & CEX & & & & & & 12 & 30 & & & & & \\
\hline \multirow{2}{*}{ P. mirabilis 42 strains } & FR10612 & & & & & & 3 & 21 & 16 & & 2 & & \\
\hline & CEX & & & & & & & 1 & 25 & 14 & 2 & & \\
\hline
\end{tabular}

Medium: HI-Agar (Difco), Inoculum: $10^{8}$ cells $/ \mathrm{ml}$, Method: Stamp method, $37^{\circ} \mathrm{C}$, 20 hours and cephalexin.

The MICs of FR10612 against 42 strains of $E$. coli ranged from 1.56 to $>100 \mu \mathrm{g} / \mathrm{ml}$, and $36(85.7 \%)$ of the 42 strains tested were inhibited at $12.5 \mu \mathrm{g} / \mathrm{ml}$ or less. Thirty seven of these strains were inhibited by $12.5 \mu \mathrm{g} / \mathrm{ml}$ or less of cephalexin. Of the 42 test strains, $4(9.5 \%)$ were resistant to FR10612 and cephalexin.

The MICs of FR10612 against $K$. pneumoniae ranged from 1.56 to $6.25 \mu \mathrm{g} / \mathrm{ml}$ with a median value of $3.13 \mu \mathrm{g} / \mathrm{ml}$ (33 strains, $78.6 \%$ ). The MICs of cephalexin ranged from 3.13 to 6.25 $\mu \mathrm{g} / \mathrm{ml}$ with a peak at $6.25 \mu \mathrm{g} / \mathrm{ml}$ (30 strains, $71.4 \%$ ).

The MICs of FR10612 against 42 strains of $P$. mirabilis ranged from 3.13 to $50 \mu \mathrm{g} / \mathrm{ml}$. Of 
these strains, $24(57.1 \%)$ were inhibited by FR10612 at $6.25 \mu \mathrm{g} / \mathrm{ml}$ or less. The sensitivity of these strains to cephalexin was slightly lower than that to FR10612. No strains which were highly resistant to FR10612 and cephalexin were noted, but strains moderately resistant to the both antibiotics at MIC of 25 to $50 \mu \mathrm{g} / \mathrm{ml}$ were found (2 strains $(4.8 \%$ ) for FR10612 and 16 (38.1\%) for cephalexin).

From the above data, it appears that there are differences between FR10612 and cephalexin in antimicrobial activity against $K$. pneumoniae and $P$. mirabilis. The antimicrobial activity of FR10612 was greater than cephalexin.

FR10612 was inactive against bacteria which are generally resistant to cephalosporins, i.e., indole-positive Proteus group, Enterobacter aerogenes, Enterobacter cloacae, Citrobacter freundii and Serratia marcescens.

\section{Influence of Various Factors on Antimicrobial Activity}

The antimicrobial activity of FR10612 was compared using 5 conventional agar media. As shown in Table 3, no particular differences in the activity were noted in any of the media tested. The antimicrobial activity of FR10612 was determined at different pHs (pH 5.4 9.4), and no significant differences were seen except that the antimicrobial activity against $E$. coli and $K$. pneumoniae decreased slightly at $\mathrm{pH}$ 5.4. The antimicrobial activity of FR10612 varied according to the inoculum size. This tendency was especially marked for $E$. coli and $K$. pneumoniae. Similar results were obtained with cephalexin. To examine the possible effect of addition of serum on the activity of FR10612, MICs of this antibiotic were determined on HIagar containing rabbit serum at concentrations of 25 and $50 \%$. No changes in antimicrobial activity of FR10612 were observed in the presence of rabbit serum.

\section{Bactericidal Activity}

The bactericidal activity of an antibiotic generally varies according to the experimental conditions, i.e., drug concentration, period of contact between drug and organism, and the growth phase of the bacteria tested. Therefore, the bactericidal activity of FR10612 was studied under various experimental conditions, using cephalexin and cefazolin as the control drugs.

(1) Effect of drug concentrations and contact periods

1.5-hour contact: HI-broths containing $8 \times 10^{5}$ cells $/ \mathrm{ml}$ of $E$. coli 324 were incubated with FR10612 or the control drugs at the MIC up to 50 times the MIC at $37^{\circ} \mathrm{C}$ for 1.5 hours. Viable cell counts were then determined. As is shown in Fig. 2a, increasing the concentration of FR10612 and cephalexin over the MIC did not increase bacterial killing. In the case of CEZ, however, the viable cell counts decreased to $1 \times 10^{5}$ cells $/ \mathrm{ml}$ at the $\mathrm{MIC}$ and to $2 \times 10^{4}$ cells $/ \mathrm{ml}$ at $50 \mathrm{MIC}$.

3.0-hour contact: The test organisms were incubated for 3 hours under the conditions mentioned above. Viable cell counts were then determined (Fig. 2b). The counts in the presence of FR10612 or cephalexin at the MIC decreased from $8 \times 10^{5}$ to $5 \times 10^{3}$ cells $/ \mathrm{ml}$. Bactericidal activity of both drugs was not increased at higher concentrations. Viable cell counts at the MIC of cefazolin decreased to $2 \times 10^{2}$ cells $/ \mathrm{ml}$, and likewise did not decrease further in the presence of higher concentrations of the drug.

6.0-hour contact: The test organisms were incubated with the antibiotics for 6 hours in 
Table 3. Influence of various factors on the antimicrobial activity of FR10612 and cephalexin.

\begin{tabular}{|c|c|c|c|c|c|}
\hline & \multirow{2}{*}{ Factor } & \multirow{2}{*}{ Antibiotics } & \multicolumn{3}{|c|}{ MIC: $\mu \mathrm{g} / \mathrm{ml}$} \\
\hline & & & $\begin{array}{l}S \text {. aureus } \\
\text { 209P JC-1 }\end{array}$ & $\begin{array}{c}E . \text { coli } \\
\text { NIHJ JC-2 }\end{array}$ & $\begin{array}{c}\text { K. pneumoniae } \\
149\end{array}$ \\
\hline \multirow{2}{*}{ Medium } & $\begin{array}{l}\text { Nutrient agar (Difco) } \\
\text { HI agar (Difco) } \\
\text { Trypticase soy agar (BBL) } \\
\text { BHI agar (Difco) } \\
\text { Mueller HiNToN agar (Difco) }\end{array}$ & FR10612 & $\begin{array}{l}0.78 \\
1.56 \\
3.13 \\
1.56 \\
1.56\end{array}$ & $\begin{array}{l}12.5 \\
12.5 \\
12.5 \\
12.5 \\
12.5\end{array}$ & $\begin{array}{l}6.25 \\
3.13 \\
3.13 \\
6.25 \\
3.13\end{array}$ \\
\hline & $\begin{array}{l}\text { Nutrient agar (Difco) } \\
\text { HI agar (Difco) } \\
\text { Trypticase soy agar (BBL) } \\
\text { BHI agar (Difco) } \\
\text { MuELLER HiNTON agar (Difco) }\end{array}$ & Cephalexin & $\begin{array}{l}0.78 \\
3.13 \\
3.13 \\
3.13 \\
3.13\end{array}$ & $\begin{array}{c}6.25 \\
12.5 \\
6.25 \\
12.5 \\
6.25\end{array}$ & $\begin{array}{r}12.5 \\
6.25 \\
6.25 \\
6.25 \\
6.25\end{array}$ \\
\hline \multirow{2}{*}{$\mathrm{pH}$} & $\begin{array}{l}5.4 \\
6.4 \\
7.4 \\
8.4 \\
9.4\end{array}$ & FR10612 & $\begin{array}{r}\leqq \\
0.1 \\
0.78 \\
0.78 \\
1.56 \\
1.56\end{array}$ & $\begin{array}{l}25 \\
12.5 \\
12.5 \\
25 \\
25\end{array}$ & $\begin{array}{l}25 \\
6.25 \\
3.13 \\
6.25 \\
6.25\end{array}$ \\
\hline & $\begin{array}{l}5.4 \\
6.4 \\
7.4 \\
8.4 \\
9.4\end{array}$ & Cephalexin & $\begin{array}{c}\leqq 0.1 \\
0.2 \\
0.78 \\
0.78 \\
0.78\end{array}$ & $\begin{array}{l}50 \\
12.5 \\
12.5 \\
25 \\
25\end{array}$ & $\begin{array}{l}25 \\
12.5 \\
6.25 \\
6.25 \\
12.5\end{array}$ \\
\hline \multirow{2}{*}{$\begin{array}{l}\text { Inoculum } \\
\text { size }\end{array}$} & $\begin{array}{l}10^{5} \\
10^{8} \\
10^{4}\end{array}$ & FR10612 & $\begin{array}{l}3.13 \\
1.56 \\
0.78\end{array}$ & $\begin{array}{r}100 \\
6.25 \\
6.25\end{array}$ & $\begin{array}{r}>100 \\
3.13 \\
1.56\end{array}$ \\
\hline & $\begin{array}{l}10^{5} \\
10^{5} \\
10^{4}\end{array}$ & Cephalexin & $\begin{array}{l}3.13 \\
1.56 \\
0.78\end{array}$ & $\begin{array}{r}>100 \\
12.5 \\
6.25\end{array}$ & $\begin{array}{r}>100 \\
6.25 \\
6.25\end{array}$ \\
\hline \multirow{2}{*}{ Serum* } & $\begin{array}{r}0 \\
25 \\
50\end{array}$ & FR10612 & $\begin{array}{l}1.56 \\
1.56 \\
1.56\end{array}$ & $\begin{array}{l}6.25 \\
6.25 \\
6.25\end{array}$ & $\begin{array}{l}3.13 \\
3.13 \\
3.13\end{array}$ \\
\hline & $\begin{array}{r}0 \\
25 \\
50\end{array}$ & Cephalexin & $\begin{array}{l}1.56 \\
1.56 \\
1.56\end{array}$ & $\begin{array}{l}12.5 \\
6.25 \\
6.25\end{array}$ & $\begin{array}{l}6.25 \\
6.25 \\
6.25\end{array}$ \\
\hline
\end{tabular}

* Serum: Rabbit, Medium: HI agar, Inoculum size: $10^{3}$ cells $/ \mathrm{ml}$

the above-mentioned manner. As shown in Fig. $2 \mathrm{c}$, viable cell counts decreased from $8 \times 10^{5}$ to $5 \times 10^{2}$ cells $/ \mathrm{ml}$ in the presence of FR10612 or cephalexin at the MIC. As in the case of 1.5-hour and 3.0-hour contacts, viable cell counts changed minimally in the presence of higher concentrations of both antibiotics. At the MIC of cefazolin, viable cell counts decreased from $8 \times 10^{5}$ to $20 \sim 30$ cells $/ \mathrm{ml}$. Again, no significant differences in viable cell counts were noted in the presence of higher concentrations of cefazolin.

Thus, the bactericidal activity of FR10612 is not enhanced by increasing the concentration 
Fig. 2. Bactericidal activity as a function of drug concentration. Test strain; E. coli 324.

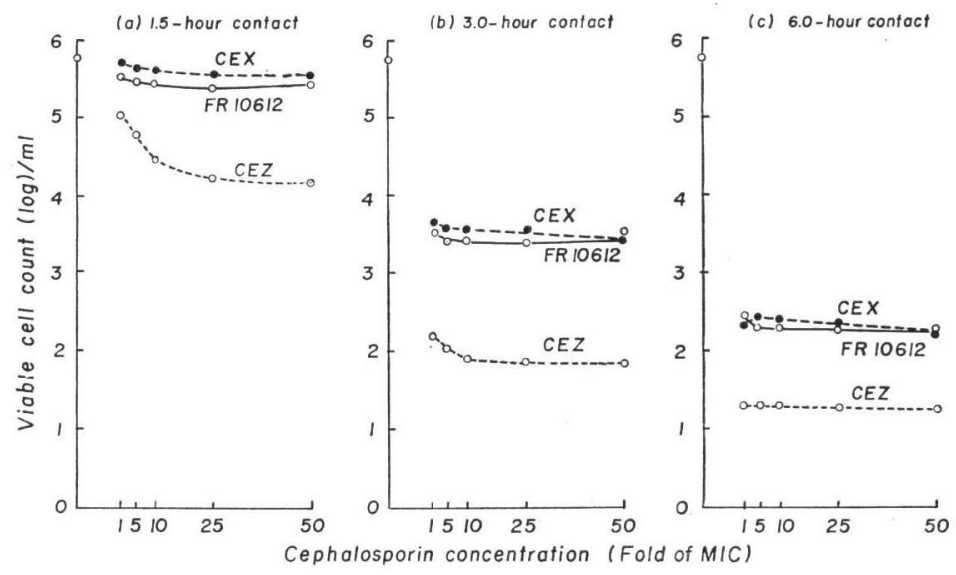

Fig. 3. Bactericidal activity in model systems simulating human serum levels after oral administration $(500 \mathrm{mg})$ of FR10612 and cephalexin.

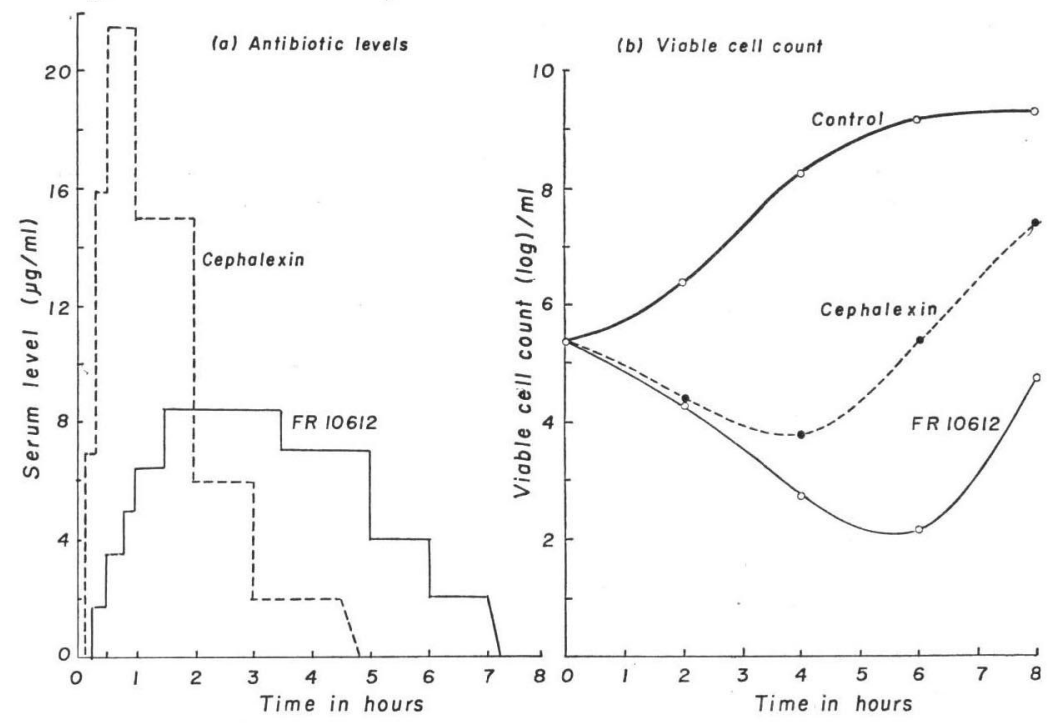

of the drug over the MIC, but it is markedly enhanced by prolonging the contact period. A similar tendency was noted for cephalexin and cefazolin. The bactericidal activity of FR10612 during each contact period was similar to that of cephalexin. Both were weaker than that of cefazolin.

(2) In vitro bactericidal activity in a model system simulating human serum levels

After a single oral dose of $500 \mathrm{mg}$ was given to healthy volunteers, the serum levels of FR10612 and cephalexin were significantly different. Whereas cephalexin peaked soon after administration and decreased rapidly, the serum levels of FR10612, which peaked at lower levels than those of cephalexin, persisted in the serum for a comparatively long period of time. Serum levels of both antibiotics after a single oral dose of $500 \mathrm{mg}$ were simulated in vitro, using HI-broths. The bactericidal activity of both antibiotics against E. coli 317 was compared in this model system. 
Fig. 3a shows the change in concentration of the antibiotics in the model system after a $500 \mathrm{mg}$ oral dose of FR10612 and cephalexin. Fig. 3b shows the change in viable cell counts in each model system. Without antibiotics, viable cell counts increased to $1.5 \times 10^{9}$ cells/ $\mathrm{ml}$ at 6 hour. With cephalexin, viable cell counts decreased from $2.4 \times 10^{5}$ to $5.5 \times 10^{3}$ cells $/ \mathrm{ml}$ at 4 hour but returned to the initial cell count at 6 hour and increased to $2.5 \times$ $10^{7}$ cells $/ \mathrm{ml}$ at 8 hour. With FR10612, viable cell counts were $4.7 \times 10^{2}$ cells $/ \mathrm{ml}$ at 4 hour and continued to decrease to $1.5 \times 10^{2}$ cells $/ \mathrm{ml}$ at 6 hour. However, over the next 2 hours the count returned to the initial cell count.

\section{Serum-protein Binding}

The binding rate of FR10612 to human and animal serum proteins was determined by centrifugal ultrafiltration. As shown in Table 4, the binding rate of FR10612 to human serum protein was $13 \%$, i.e., it was the same as or even slightly lower than that of cephalexin. A similar tendency was noted for dog, rabbit and rat serum proteins.

6. Hydrolysis of Test Antibiotics by $\beta$-Lactamase

Hydrolysis of FR10612 by $\beta$-lactamases isolated from various gram-negative bacilli was expressed as a relative percentage using cefazolin as $100 \%$ (Table 5). FR10612 was more readily hydrolyzed than cefazolin by $\beta$-lactamases of 2 of the 8 strains tested, but was more resistant than cefazolin to the other

Table 4. Protein binding of FR10612 and other cephalosporins.

\begin{tabular}{c|c|c|c|c}
\hline \multirow{2}{*}{ Drug } & \multicolumn{4}{|c}{$\%$ Bound } \\
\cline { 2 - 5 } & Human & Dog & Rabbit & Rat \\
\cline { 2 - 5 } FR10612 & 13 & 17 & 15 & 29 \\
CEX & 20 & 13 & 20 & 32 \\
CEZ & 92 & 54 & 92 & 94 \\
CER & 55 & 22 & 55 & 67 \\
CET & 86 & 44 & 86 & 87 \\
\hline
\end{tabular}

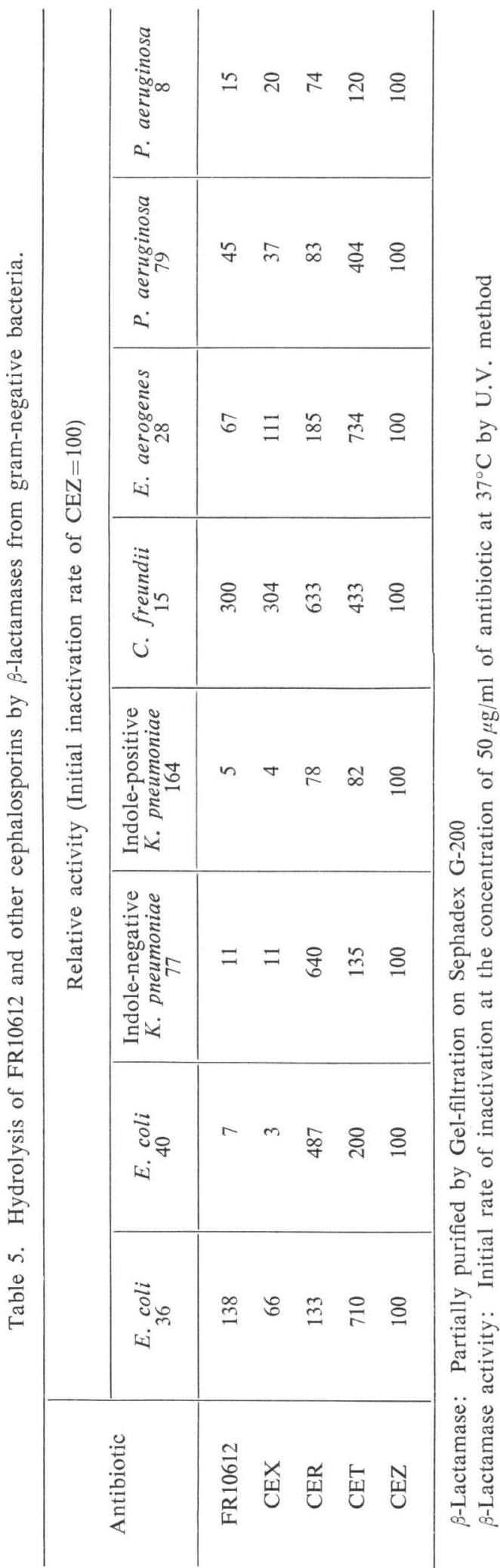


Table 6. Protective effect of FR10612, cephalexin and ampicillin against experimental infections in mice.

\begin{tabular}{|c|c|c|c|c|c|c|c|c|c|c|c|c|}
\hline \multirow{3}{*}{ Organism } & \multirow{3}{*}{$\begin{array}{l}\text { Challenge } \\
\text { (cells/mouse) }\end{array}$} & \multirow{3}{*}{$\begin{array}{c}\text { Mucin } \\
(\%)\end{array}$} & \multicolumn{4}{|c|}{$\mathrm{ED}_{50}: \mathrm{mg} /$ mouse } & \multicolumn{6}{|c|}{ MIC: $\mu \mathrm{g} / \mathrm{ml}$} \\
\hline & & & \multirow{2}{*}{ FR10612 } & \multirow{2}{*}{ CEX } & \multirow{2}{*}{$\frac{\text { CEX }}{\text { FR10612 }}$} & \multirow{2}{*}{ A BPC } & \multicolumn{2}{|c|}{ FR10612 } & \multicolumn{2}{|c|}{ CEX } & \multicolumn{2}{|c|}{$\mathrm{ABPC}$} \\
\hline & & & & & & & $10^{8}$ & $10^{8}$ & $10^{8}$ & $10^{8}$ & $10^{8}$ & $10^{8}$ \\
\hline S. aureus 13 & $2.9 \times 10^{7}$ & 0 & $\begin{array}{c}0.06 \\
(0.03 \sim 0.11)\end{array}$ & $\begin{array}{c}0.19 \\
(0.07 \sim 0.45)\end{array}$ & 3.2 & $>20$ & 6.25 & 3.13 & 6.25 & 3.13 & 200 & 1.56 \\
\hline S. aureus 26 & $1.0 \times 10^{9}$ & 0 & $\begin{array}{c}1.0 \\
(0.4 \sim 2.5)\end{array}$ & $\begin{array}{c}3.4 \\
(1.8 \sim 6.8)\end{array}$ & 3.4 & $>20$ & 6.25 & 3.13 & 12.5 & 6.25 & 400 & 3.13 \\
\hline E. coli 19 & $8.0 \times 10^{4}$ & 2 & $\begin{array}{c}0.03 \\
(0.02 \sim 0.04)\end{array}$ & $\begin{array}{c}0.11 \\
(0.08 \sim 0.16)\end{array}$ & 3.7 & $\begin{array}{c}0.28 \\
(0.17 \sim 0.50)\end{array}$ & 12.5 & 6.25 & 12.5 & 6.25 & 3.13 & 3.13 \\
\hline E. coli 9 & $4.7 \times 10^{3}$ & 2 & $\begin{array}{c}0.04 \\
(0.03 \sim 0.06)\end{array}$ & $\begin{array}{c}0.1 \\
(0.06 \sim 0.19)\end{array}$ & 2.5 & $\begin{array}{c}0.48 \\
(0.28 \sim 0.88)\end{array}$ & 25 & 6.25 & 12.5 & 6.25 & 6.25 & 6.25 \\
\hline E. coli 33 & $7.5 \times 10^{3}$ & 2 & $\begin{array}{c}0.02 \\
(0.01 \sim 0.05)\end{array}$ & $\begin{array}{c}0.08 \\
(0.04 \sim 0.14)\end{array}$ & 4.0 & $\begin{array}{c}0.14 \\
(0.10 \sim 0.19)\end{array}$ & 12.5 & 6.25 & 12.5 & 12.5 & 3.13 & 1.56 \\
\hline K. pneumoniae 1 & $6.5 \times 10^{3}$ & 2 & $\begin{array}{c}0.04 \\
(0.03 \sim 0.05)\end{array}$ & $\begin{array}{c}0.20 \\
(0.10 \sim 0.43)\end{array}$ & 5.0 & $>20$ & 50 & 3.13 & 50 & 6.25 & $>400$ & 25 \\
\hline K. pneumoniae 12 & $4.0 \times 10^{4}$ & 5 & $\begin{array}{c}0.02 \\
(0.01 \sim 0.04)\end{array}$ & $\begin{array}{c}0.13 \\
(0.09 \sim 0.18)\end{array}$ & 6.5 & $>20$ & 50 & 6.25 & 50 & 6.25 & $>400$ & 200 \\
\hline P. mirabilis 16 & $6.8 \times 10^{8}$ & 5 & $\begin{array}{c}0.14 \\
(0.08 \sim 0.25)\end{array}$ & $\begin{array}{c}1.17 \\
(0.81 \sim 4.8)\end{array}$ & 8.4 & $\begin{array}{c}0.09 \\
(0.04 \sim 0.17)\end{array}$ & 12.5 & 6.25 & 25 & 12.5 & 3.13 & 1.56 \\
\hline P. mirabilis 4 & $6.5 \times 10^{5}$ & 5 & $\begin{array}{c}0.06 \\
(0.032 \sim 0.11)\end{array}$ & $\begin{array}{c}0.56 \\
(0.42 \sim 0.75)\end{array}$ & 9.3 & $\begin{array}{c}0.05 \\
(0.04 \sim 0.08)\end{array}$ & 25 & 12.5 & 100 & 25 & 6.25 & 3.13 \\
\hline
\end{tabular}


$6 \beta$-lactamases. Cephalexin is generally known to be resistant to $\beta$-lactamase. As indicated, the resistance of FR10612 to $\beta$-lactamase was nearly the same as that of cephalexin.

\section{Protective Effect in Mice}

The protective effect of oral doses of FR10612 in mice at one hour after intraperitoneal challenge with various pathogens was compared with that of cephalexin and ampicillin. As is shown in Table 6, 2 strains of $S$. aureus, 3 strains of E. coli, 2 strains of $K$. pneumoniae and 2 strains of $P$. mirabilis were used as the test strains. At an inoculum of $10^{6} \mathrm{cells} / \mathrm{ml}$, these strains were sensitive to both FR10612 and cephalexin. The MICs of FR10612 and cephalexin against these strains were almost the same. The $\mathrm{ED}_{50}$ values of cephalexin, however, were 2.5 9.3 times greater than those of FR10612. The protective effect of FR10612 in mice experimentally infected with the test strains was thus greater than that of cephalexin. Against the 4 strains resistant to ampicillin at a high inoculum $\left(10^{8} \mathrm{cells} / \mathrm{ml}\right)$, ampicillin was ineffective. FR10612 was effective against these strains. The protective effect of ampicillin against infections due to the other 5 strains which were ampicillin sensitive was less than that of FR10612.

Fig. 4. Serum levels of FR10612 and cephalexin after oral administration $(100 \mathrm{mg} / \mathrm{kg})$ in rats.

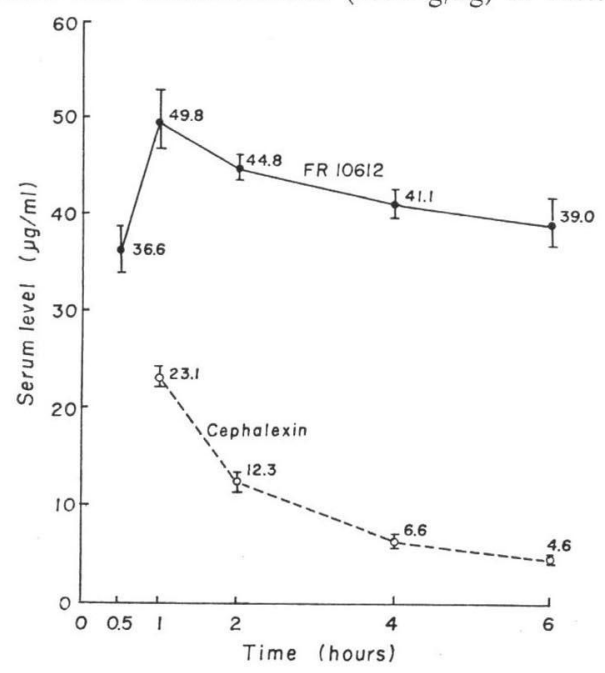

\section{Serum Levels}

As is shown in Fig. 4, the serum levels of FR10612 in rats were very high and were maintained for a long period of time. The serum levels peaked at a mean of $49.8 \mu \mathrm{g} / \mathrm{ml}$ one hour after administration and were 39.0 $\mu \mathrm{g} / \mathrm{ml}$ at 6 hours. On the other hand, the serum levels of cephalexin were $23.1 \mu \mathrm{g} / \mathrm{ml}$ at one hour and $4.6 \mu \mathrm{g} / \mathrm{ml}$ at 6 hours.

Fig. 5 shows the serum levels of FR10612 and cephalexin in rabbits after 3 repeated oral doses of $40 \mathrm{mg} / \mathrm{kg}$ given at 4.5 -hour intervals. The peak serum levels of FR10612 ranged from 8.6 to $10.9 \mu \mathrm{g} / \mathrm{ml}$. These were lower than the peak levels of cephalexin

Fig. 5. Serum levels of FR10612 and cephalexin after oral repeated doses (40 mg/kg) in rabbits.

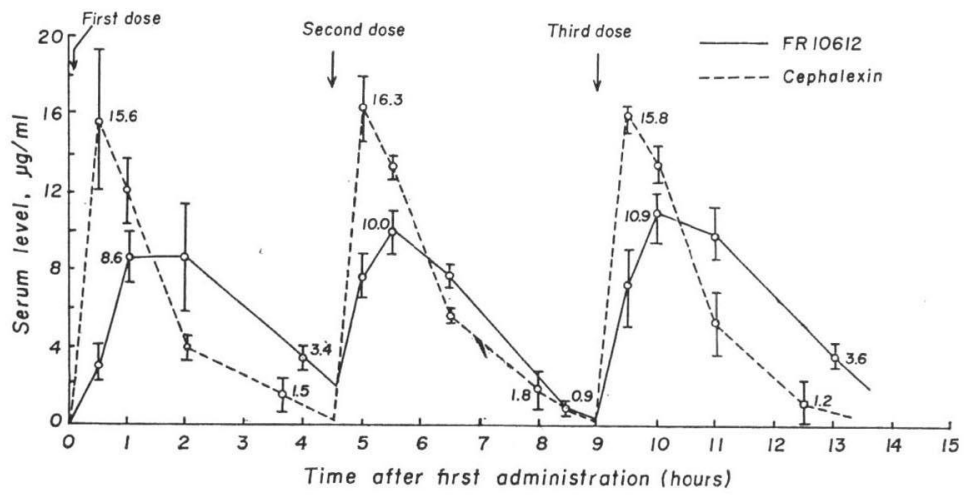


Fig. 6. Serum levels of FR10612 and cephalexin after oral administration $(40 \mathrm{mg} / \mathrm{kg})$ in dogs.

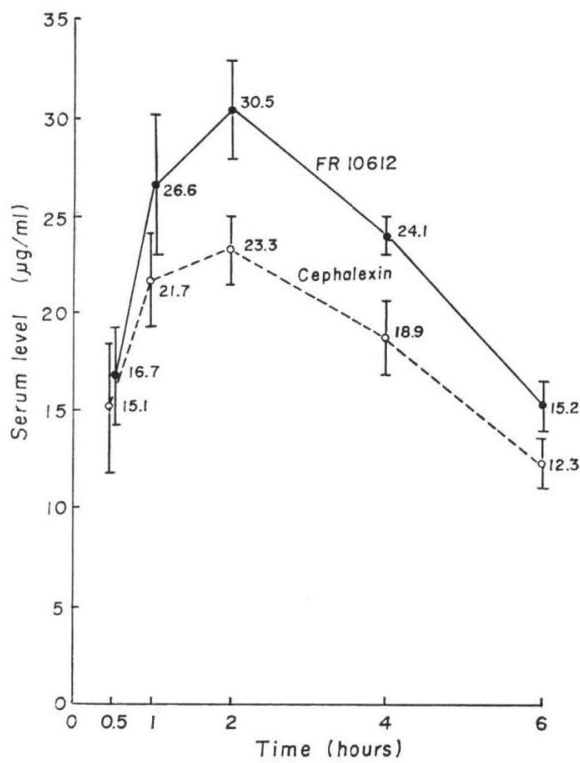

Fig. 7. Serum levels of FR10612 and cephalexin after oral administration $(40 \mathrm{mg} / \mathrm{kg})$ in monkeys.

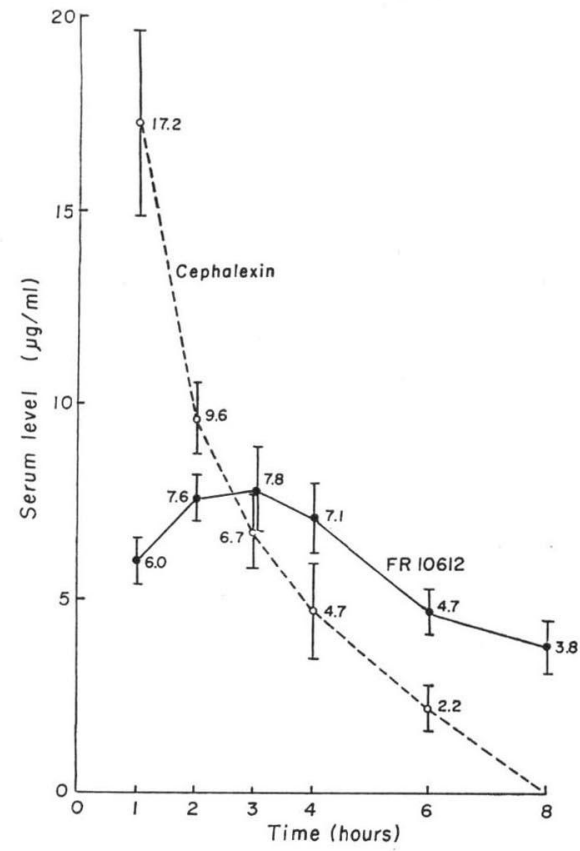

Fig. 8. Urinary excretion of FR10612 and cephalexin after oral administration $(100 \mathrm{mg} / \mathrm{kg})$ in rats.

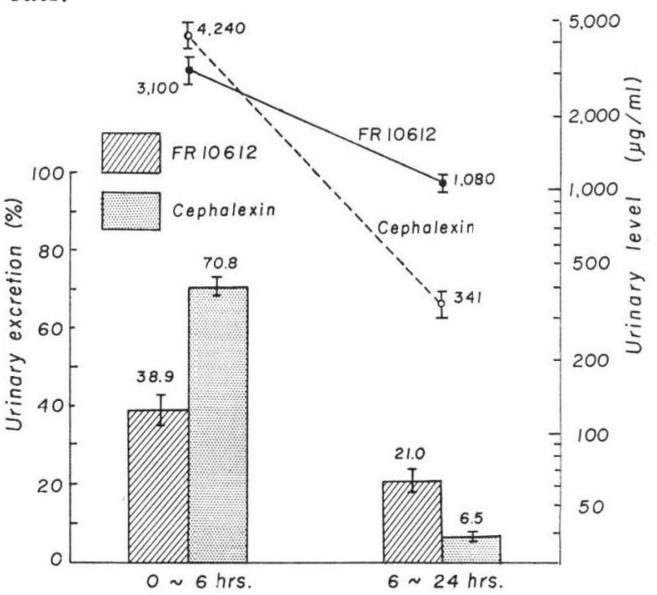

Fig. 9. Urinary excretion of FR10612 and cephalexin after oral administration $(40 \mathrm{mg} / \mathrm{kg})$ in dogs.

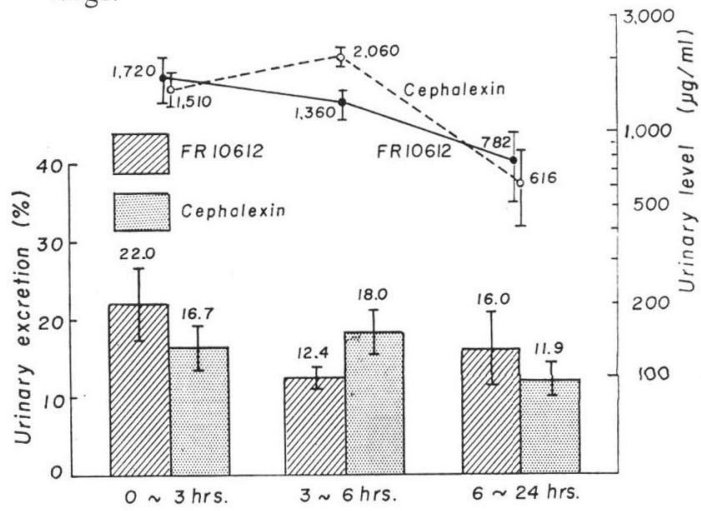

$(15.6 \sim 16.3 \mu \mathrm{g} / \mathrm{ml})$ but later the levels tended to become higher than those of cephalexin.

As is clearly shown in Fig. 6, the serum levels of FR10612 in dogs were generally higher than those of cephalexin but they were not as persistently elevated as in the rats.

As is shown in Fig. 7, the patterns of the serum levels of FR10612 and cephalexin in monkeys were very similar to those in

rabbits. With FR10612, the peak levels $(7.1 \sim 7.8 \mu \mathrm{g} / \mathrm{ml})$ were maintained for $2 \sim 4$ hours after administration. A concentration of $3.8 \mu \mathrm{g} / \mathrm{ml}$ persisted for 8 hours after administration. On the other hand, cephalexin peaked at $17.2 \mu \mathrm{g} / \mathrm{ml}$ one hour after administration and was 9.6 $\mu \mathrm{g} / \mathrm{ml}$ at 2 hours. These levels were higher than FR10612. However, the levels of cephalexin at 3 hours and there-after were lower than those of FR10612. 
Fig. 10. Urinary excretion of FR10612 and cephalexin after oral administration $(40 \mathrm{mg} / \mathrm{kg})$ in monkeys.

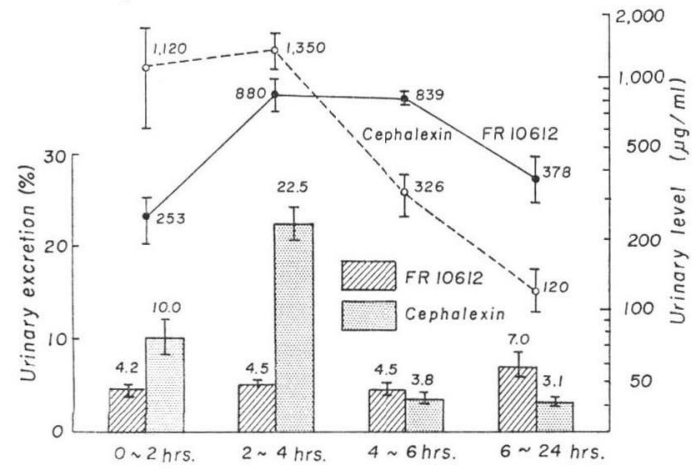

Fig. 11. Biliary excretion of FR10612 and cephalexin after oral administration $(100 \mathrm{mg} / \mathrm{kg})$ in rats.

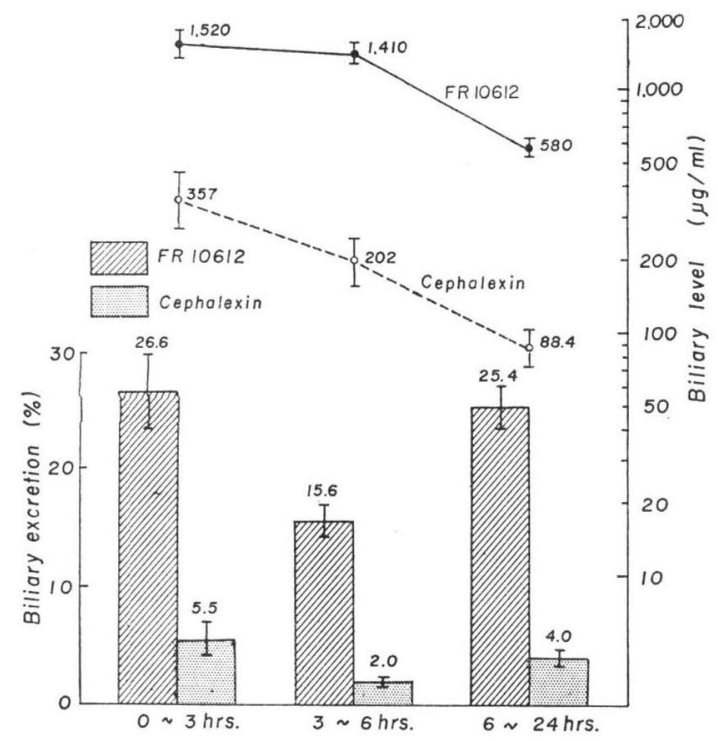

Fig. 12. Tissue levels of FR10612 after oral administration $(100 \mathrm{mg} / \mathrm{kg})$ in rats and mice.
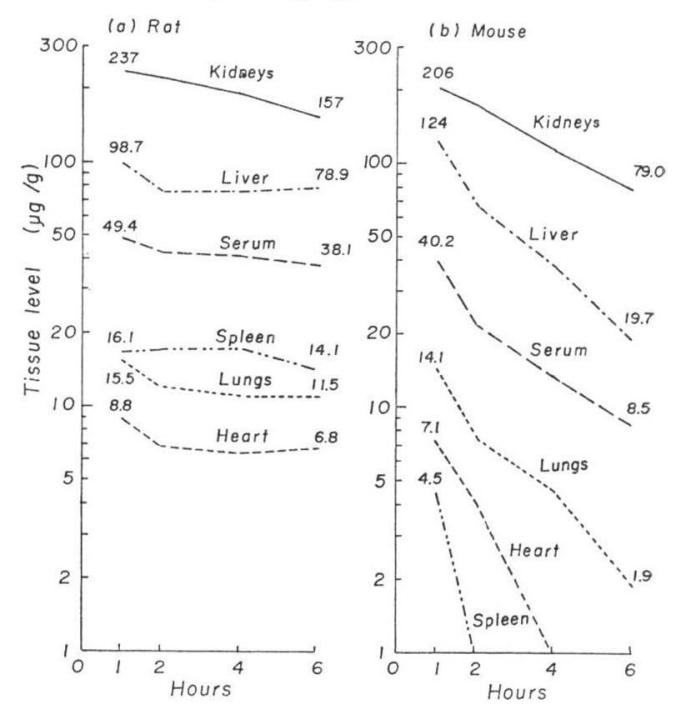

9. Urinary Excretion

Fig. 8 shows the urinary excretion of the test drugs in rats. Total recovery of FR10612 in a 24-hour urine collection was $59.9 \%$; this was lower than that of cephalexin (77.3\%). This recovery rate appeared to be low when one considered the high serum levels of FR10612 in rats. These results suggest other possible routes of excretion of FR10612 in rats. Of the total amount recovered in the urine within 24 hours, about $65 \%$ of FR10612 and more than $90 \%$ of cephalexin were excreted within 6 hours after administration of the drug.

As is shown in Fig. 9, recovery rate of FR10612 in dogs in a 24-hour urine collection was $50.4 \%$ and that of cephalexin was $46.6 \%$. No significant differences in urinary concentrations were thus noted between FR10612 and cephalexin.

Fig. 10 shows that the recovery rate of both drugs in monkeys in a 24-hour urine collection was very low (18.0\% for FR10612 and $39.4 \%$ for cephalexin).

Thus, the urinary levels of FR10612 after oral administration differed significantly according to the animal species as did the serum levels.

10. Biliary Excretion

Fig. 11 shows the biliary excretion of both antibiotics in rats. The recovery rate of FR10612 in a 24-hour bile collection was $67.6 \%$; this was higher than that of cephalexin $(11.5 \%)$. Furthermore, biliary levels of FR10612 in rats were several times higher than those of cephalexin. 


\section{Tissue Distribution}

Fig. 12a shows the tissue levels of FR10612 in SD strain rats after a single oral administration of $100 \mathrm{mg} / \mathrm{kg}$. The tissue levels of FR10612 one hour after administration were $237 \mu \mathrm{g} / \mathrm{g}$ in the kidneys and $98.7 \mu \mathrm{g} / \mathrm{g}$ in the liver. These tissue levels were higher than the serum levels (49.4 $\mu \mathrm{g} / \mathrm{ml})$. FR10612 also was well distributed in the spleen $(16.1 \mu \mathrm{g} / \mathrm{g})$ lungs $(15.5 \mu \mathrm{g} / \mathrm{g})$ and heart $(8.8 \mu \mathrm{g} / \mathrm{g})$. Like the serum levels, the tissue levels of FR10612 did not decrease markedly even 6 hours after administration.

Fig. 12b represents the tissue levels of FR10612 in ICR-strain mice after a single oral administration of $100 \mathrm{mg} / \mathrm{kg}$. The tissue levels of FR10612 in mice one hour after administration were $206 \mu \mathrm{g} / \mathrm{g}$ in the kidneys, $124 \mu \mathrm{g} / \mathrm{g}$ in the liver, both being higher than the serum level $(40.2 \mu \mathrm{g} / \mathrm{ml}), 14.1 \mu \mathrm{g} / \mathrm{g}$ in the lungs, $7.1 \mu \mathrm{g} / \mathrm{g}$ in the heart and $4.5 \mu \mathrm{g} / \mathrm{g}$ in the spleen.

12. Antibiotic Levels in the Exudate of Rats with a Granuloma Pouch

As is shown in Fig. 13, the serum levels of FR10612 in rats after a single oral dose of $100 \mathrm{mg} / \mathrm{kg}$ peaked at $46.9 \mathrm{ug} / \mathrm{ml}$ one hour after administration and were $38.5 \mu \mathrm{g} / \mathrm{ml}$ at 8 hours.

Fig. 13. Exudate and serum levels of FR10612 and cephalexin after oral administration (100 $\mathrm{mg} / \mathrm{kg}$ ) in rats with granuloma pouch.

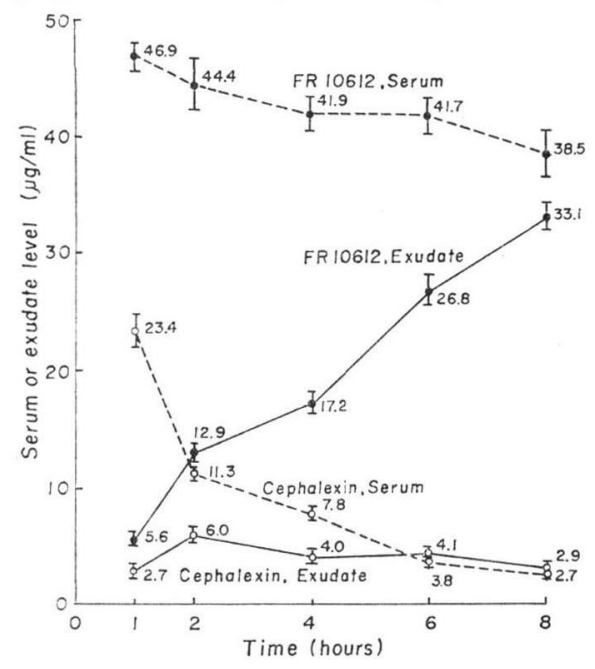

Fig. 14. Serum levels of FR10612 and cephalexin after oral administration $(250 \mathrm{mg} / \mathrm{man})$ in healthy volunteers.

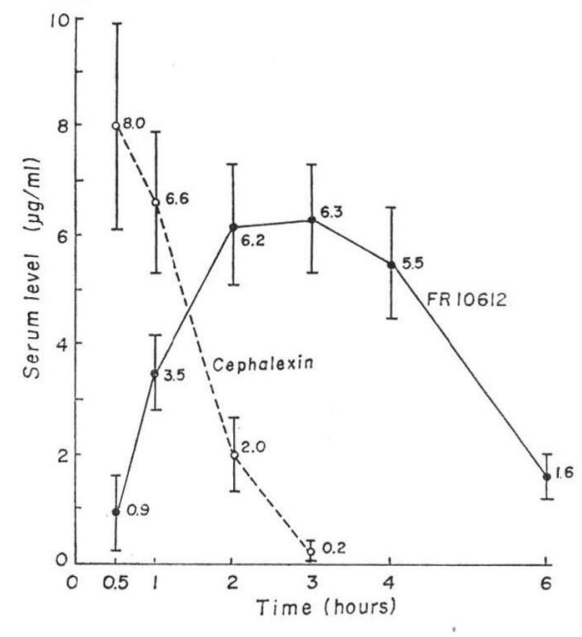

The antibiotic concentrations in pouch exudates gradually increased with time reaching 33.1 $\mu \mathrm{g} / \mathrm{ml}$ at 8 hours after administration, i.e., almost the same as the 8-hour serum levels. The serum levels of cephalexin peaked at $23.4 \mu \mathrm{g} / \mathrm{ml}$ one hour after a single oral administration of $100 \mathrm{mg} / \mathrm{kg}$. Antibiotic levels in the pouch exudates reached $2.7 \mu \mathrm{g} / \mathrm{ml}$ at one hour and peaked at $6.0 \mu \mathrm{g} / \mathrm{ml}$ at 2 hours. However, cephalexin levels in the exudate did not increase further.

13. Absorption and Excretion of Test Drugs in Healthy Volunteers

(1) Serum levels

The mean serum levels of FR10612 and cephalexin in 6 healthy volunteers after an oral cross-over administration of $250 \mathrm{mg}$ in the fasting state are shown in Fig. 14. FR10612 was slowly absorbed and the serum levels of FR10612 peaked at $6.2 \sim 6.3 \mu \mathrm{g} / \mathrm{ml} 2 \sim 3$ hours after administration. FR10612 in the serum gradually decreased to $5.5 \mu \mathrm{g} / \mathrm{ml}$ at 4 hours and $1.6 \mu \mathrm{g} / \mathrm{ml}$ at 6 hours. Cephalexin was absorbed more rapidly than FR10612. The serum levels of cepha- 
Fig. 15. Serum levels of FR10612 and cephalexin after oral administration $(500 \mathrm{mg} / \mathrm{man})$ in healthy volunteers.

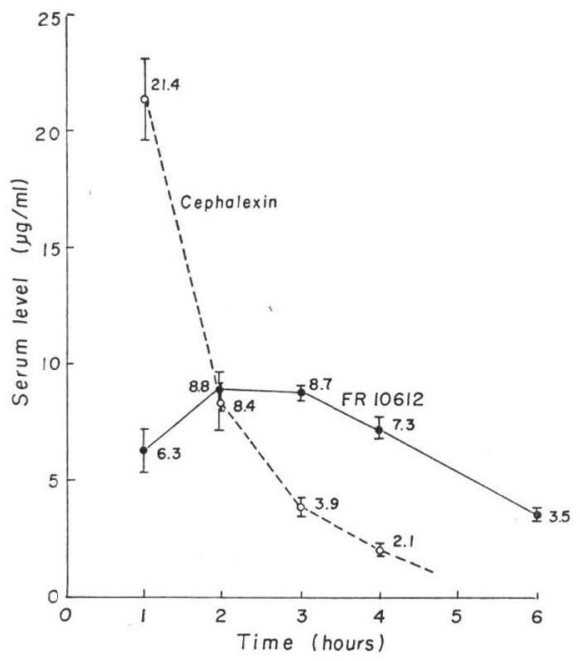

lexin peaked at $8.0 \mu \mathrm{g} / \mathrm{ml} \quad 0.5$ hours after administration and quickly decreased to 0.2 $\mu \mathrm{g} / \mathrm{ml}$ at 3 hours.

A similar tendency was noted in serum levels of both antibiotics after oral administration of $500 \mathrm{mg}$ (Fig. 15). The serum levels of FR10612 peaked at $8.7 \sim 8.8 \mu \mathrm{g} / \mathrm{ml}$ at $2 \sim 3$ hours and were well maintained at more than $3.5 \mu \mathrm{g} / \mathrm{ml}$ at 6 hours after administration. The serum levels of cephalexin peaked at $21.4 \mu \mathrm{g} / \mathrm{ml}$ at one hour which was higher than those of FR10612, but rapidly decreased to $3.9 \mu \mathrm{g} / \mathrm{ml}$ at 3 hours and thereafter remained at levels lower than those of FR10612.

(2) Urinary excretion

The urinary excretion of FR10612 and cephalexin after oral administration of $250 \mathrm{mg}$ to healthy volunteers is shown in Fig. 16. Recovery rates of FR10612 and cephalexin in the 24hour urine averaged $88.6 \%$ and $82.1 \%$ respectively. However, cephalexin was excreted more

Fig. 17. Bioautograms of urine and bile samples after oral administration of FR10612.

Thin-layer; Eastman Chromatogram sheet No. 6061 (predevelopment with $4 \%$ Silicone-Ether), Solvent system; $\mathrm{M} / 15$ Phosphate buffer ( $\mathrm{pH} 7.0$ ),

Test organism; B. subtilis ATCC 6633.

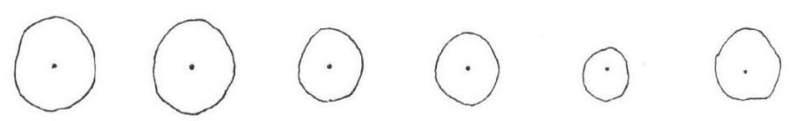

\begin{tabular}{cccccc}
\hline FRI06I2 & $0 \sim 6 \mathrm{hrs}$ & $0 \sim 3 \mathrm{hrs}$ & $0 \sim 3 \mathrm{hrs}$ & $0 \sim 2 \mathrm{hrs}$ & $0 \sim 4 \mathrm{hrs}$ \\
Standard & Urine & Bile & Urine & Urine & Urine \\
& Rats & Rats & Dogs & Monkeys Heolthy volunteers
\end{tabular}


rapidly than FR10612.

(3) Antimicrobial substances in the urine and bile

Antimicrobial substances in the urine of healthy volunteers and of animals after oral administration of FR10612 were investigated by TLC-bioautography. Antimicrobial substances in the rat bile were also investigated by the same method. As shown in Fig. 17, the antimicrobial substances in the urine of healthy volunteers as well as in all the animals and in the bile of rats had the same Rf value as FR10612. From these results, the active substance was considered to be FR10612 itself.

\section{Discussion}

FR10612 clearly demonstrated a superior therapeutic effect in mice after challenge with various pathogens when compared with cephalexin and ampicillin. However, this greater therapeutic effect could not have been predicated by comparing the in vitro performance of these drugs. The serum levels after oral administration of FR10612 both in healthy volunteers and in animals were more prolonged than those of cephalexin. The tissue levels of FR10612 in rats and mice were also found to be more persistent than the previously reported tissue levels of cephalexin ${ }^{3)}$. It might be assumed that these differences in pharmacokinetics of FR10612 and cephalexin are reflected in the above therapeutic effect. In order to test this assumption, the bactericidal activity of FR10612 was compared with that of cephalexin, using an in vitro model system which simulated the serum levels of FR10612 and cephalexin in healthy volunteers. In this system, the bactericidal activity of cephalexin was lower than that of FR10612. These results are consistent with previously reported results showing that the bactericidal effect of cephalosporin derivatives is more greatly influenced by the duration of contact than by the antibiotic concentration ${ }^{4)}$.

BARZA et al..$^{5)}$ have reported that antibiotic levels in a fibrin clot were only $19 \sim 25 \%$ of the peak level of free antibiotic in the serum. Thus, the more persistent the serum antibiotic level, the more readily the antibiotic is a balance attained between the serum and clot. In a similar manner, we have noted a balance between FR10612 levels in exudates of rats with a granuloma pouch and serum levels. It is also apparent that adequate levels of the antibiotic in the serum must be maintained for $4 \sim 5$ hours to obtain exudate levels of about half the serum levels and for about 8 hours to obtain exudate levels equal to the serum levels. Presumably, the high therapeutic effect of FR10612 in experimental infections in mice is related to its prolonged serum levels and its high concentration at the site of infection. Judging from the relatively unique distribution of FR10612 in the bile of rats, enterohepatic circulation is considered to play a role in the persistence of the serum levels of this drug.

\section{Bibliography}

1) Nishida, M.; T. Matsubara, T. Murakawa, Y. Mine, Y. Yokota, S. Kuwahara \& S. Goto: In vitro and in vivo evaluation of cefazolin, a new cephalosporin $\mathrm{C}$ derivative. Antimicr. Agents \& Chemoth.-1969: 236 243, 1970

2) Nishida, M.; T. Murakawa, T. Kamimura, N. Okada, H. Sakamoto, S. Fukada, S. Nakamoto, Y. YокотA \& K. Miki: In vitro and in vivo evaluation of ceftezole, a new cephalosporin C derivative. Antimicr. Agents \& Chemoth. (in press)

3) Sullivan, H. R.; R. E. Billings \& R. E. McMahon: Metabolism of cephalexin $-{ }^{14} \mathrm{C}$ in mice and in rats. J. Antibiotics 22: 195 200, 1969

4) Miyamoto, T.; A. Kobayashi \& S. Furiya: Quantitative analysis of bactericidal effects of the various antibiotics. Chemotherapy, (Japan) 21: 6 10, 1973

5) Barza, M.; T. Samuelson \& L. Weinstein: Penetration of antibiotics into fibrin loci in vivo. J. Inf. Dis. 129: $66 \sim 72,1974$ 